\begin{abstract}
Iranica
Abstracta Iranica Revue bibliographique pour le domaine irano-aryen

Volume 34-35-36 | 2017

Comptes rendus des publications de 2011-2013
\end{abstract}

\title{
Christelle Jullien. Les Actes des martyrs perses. Transmettre l'histoire
}

Marie-Joseph Pierre

\section{(2) OpenEdition \\ 12 Journals}

Édition électronique

URL : http://journals.openedition.org/abstractairanica/41925

DOI : 10.4000/abstractairanica.41925

ISSN : 1961-960X

\section{Éditeur :}

CNRS (UMR 7528 Mondes iraniens et indiens), Éditions de l'IFRI

\section{Référence électronique}

Marie-Joseph Pierre, "Christelle Jullien. Les Actes des martyrs perses. Transmettre I'histoire », Abstracta Iranica [En ligne], Volume 34-35-36 | 2017, document 19, mis en ligne le 30 décembre 2016, consulté le 02 octobre 2020. URL : http://journals.openedition.org/abstractairanica/41925 ; DOI : https://doi.org/ 10.4000/abstractairanica.41925

Ce document a été généré automatiquement le 2 octobre 2020.

Tous droits réservés 


\title{
Christelle Jullien. Les Actes des martyrs perses. Transmettre l'histoire
}

\author{
Marie-Joseph Pierre
}

\section{RÉFÉRENCE}

Christelle Jullien. «Les Actes des martyrs perses. Transmettre l'histoire », in : A. Binggeli, éd., L'hagiographie syriaque. Paris, 2012, p. 127-140. (Études syriaques 9)

1 L'A. présente les caractéristiques et les originalités du corpus des Actes des martyrs perses. Cette présentation fournit aussi une histoire de la recherche, elle montre les enjeux des traductions, et propose une identification plausible des auteurs de cette littérature. Tout en relevant combien, compte tenu du genre hagiographique même, ces martyrologes sont les produits d'une rhétorique, de modélisations et d'élaborations, fruits aussi de transmissions parfois complexes, l'A. souligne leur grande qualité informative quant à l'histoire des communautés chrétiennes en monde iranien.

\section{AUTEURS}

\section{MARIE-JOSEPH PIERRE}

Directrice d'Études honoraire, EPHE 